THE KURUME MEDICAL JOURNAL Vol. 10, No. 2, 1963

\title{
STUDIES ON THE IN VITRO MARKER TEST OF ECHO VIRUSES*
}

\author{
MASAHISA SHINGU, SHIGERU YAMAMOTO \\ AND YOH NAKAGAWA
}

\begin{abstract}
Department of Microbiology, Kurume University School of Medicine, Kurume-shi, Japan
\end{abstract}

(Received for publication January 31, 1963)

Within the past several yesrs, studies have been made of at least seven markers of poliovirus which can be determined by tissue culture, physical property and serological method, and which tend to discriminate between neurovirulent and attenuated strains.

Strains possessing the $\mathrm{d}^{+}$marker grow more rapidly than $\mathrm{d}^{-}$streains at low bicarbonate concentration under agar (1); strains possessing the $\mathrm{MS}^{+}$marker grow more rapidly on the monkey kidney stable cell line than MS- strains (2); strains possessing the $\mathrm{T}^{+}$marker grow readily at $40^{\circ} \mathrm{C}$ in contrast to the $\mathrm{T}$ - strains (3); $\mathrm{CF}$ antigen of strains possessing the $\mathrm{CFt}^{+}$marker are more resistent than $\mathrm{CFt}^{-}$ strains at various temperatures (4); strains possessing the $\mathrm{A}^{+}$marker grow more rapidly on the primary human amnion cell than $\mathrm{A}^{-}$strain (5); strains possessing the $\mathrm{E}^{+}$marker elute more rapidly from an DEAE column than $\mathrm{E}^{-}$strain (6).

The most promising advance in the identification of virus strains is the intratypic sero-differentiation test investigated by McBride, Gard and Wecker (7), (8),(9).

At the present time, the ECHO viruses consist of 28 serotypes. All 28 serotypes have been derived from the alimentary tract (and sometimes from the throat) of human beings. Many have been associated with outbreaks of benign aseptic meningitis (e.g., ECHO types 1, 2, 3, 4, 5, 6, 7, 8, 9, 12, 13, 14, 16, 19, 21, 24, ), and paralysis (e.g., ECHO types 2, 4, 6, 9, 11, 16).

Although considerable attention should be paid to the studies on the properties of ECHO viruses, there is as yet very little information as to the general properties of the viruses in the tissue culture. The problem of the in vitro marker of ECHO viruses, that is to say, whether the in vitro marker test can be used in the ECHO viruses employing same method as for polioviruses, has been an interesting problem in the field of virulence of enteroviruses.

The present paper deals with the multiplication of viruses in tissue culture and the in vitro marker test of ECHO viruses.

* This study was supported in part by a grant in aid for Fundamental Scientific Research from the Education Ministry (Studies on the live poliovirus vaccine, 1962) 


\section{MATERIAL AND METHODS}

Tissue culture.

MS, FL and HeLa cells as the established cell lines and primate cynomolgus monkey kidney (MK) cell were used in the present experiments. The cells were grown in bottles or tubes with $\mathrm{M}+$ Hanks solution containing $10 \%$ bovine serum for the established cell lines and $3 \%$ for MK cell (growth medium) at the temperature of $37^{\circ} \mathrm{C}$. Puck's solution was used for washing the cultures and for diluting the virus. As the maintenance medium, M+Earle's solution added $10 \%$ skim milk solution $(10 \%)$ was used.

\section{Viruses.}

The viruses used in the present studies were ECHO $1,2,3,4,5,6,66^{\prime}, 6^{\prime \prime}, 7$, $8,9,10,11,12,13,14,15,16,17,18,19,20,21,22,23,24,25,26,27$ and 28. The prototypic viruses are listed in Table 1 . Mahoney and Sabin strains of type 1 poliovirus were used as a control for plaque experiment because of the formation of a well-defined one on the cell monolayers. Stock virus was propagated in MK cell monolayers in the cysteine medium and harvested after one or two days of incubation at $37^{\circ} \mathrm{C}$. The culture was frozen and thawed to disrupt cells and centrifuged. Supernatant fluid was stored at $-20^{\circ} \mathrm{C}$ until used.

TABLE 1

ECHO viruses

\begin{tabular}{c|l|l|l}
\hline TYPE & STRAIN & TYPE & STRAIN \\
\hline 1 & Farouk & 14 & Tow \\
2 & Cornelius & 15 & Charleston \\
3 & Morrisey & 16 & Harrington \\
4 & Pesascek & 17 & CHHE-29 \\
5 & Noyce & 18 & Metcalf \\
6 & D' Amori & 19 & Burke \\
$6^{\prime}$ & D-1 (Cox) & 20 & JV-1 \\
$6^{\prime \prime}$ & Burgess & 21 & Farinea \\
7 & Wallace & 22 & Harris \\
8 & Bryson & 23 & Williamson \\
9 & Hill & 24 & De Camp \\
10 & Lang & 25 & JV-4 \\
11 & Gregory & 26 & Coronel 11-3-6 \\
12 & Trivis 2-85 & 27 & Bacon 1-36-4 \\
13 & Hamphil1 11-4-D & 28 & 2060 \\
\hline
\end{tabular}

\section{Titration of the viruses used.}

Serial 10-fold dilutions of the infected nutrient fluid to be tested were made, and $0.1 \mathrm{ml}$ of each dilution was introduced into 4 tubes which contained $1.0 \mathrm{ml}$ of the medium. Four days after inoculation the tubes were examined microscopically for evidence of specific degeneration, and the result was expressed in terms of TCD 50 
which was calculated by the Behrens-Kärber formula.

\section{Plaque formation.}

The cell monolayer grown in the bottle was washed once with Puck's solution, maintenance medium added, and virus inoculation was done after 24 hours. After removal of the maintenance medium, the monolayer was washed with Puck's solution and inoculated with $0.2 \mathrm{ml}$ of appropriate dilution of viruses in Puck's solution. After adsorption for 1 hour, agar overlay was added. The overlay consisted of 1.5 $\%$ agar (Difco Bacto) in Hank's BSS containing $2 \%$ calf serum, $0.22 \%$ sodium bicarbonate and neutral red at a concentration of $1: 60,000$. In the case in which MK cell was used, Earle's solution was substituted for Hank's BSS. After the agar had solidified, the bottles were kept at $37^{\circ} \mathrm{C}$ for 3 or 5 days. The number and the size of plaques were observed.

Neutralization test.

$0.4 \mathrm{ml}$ of the serum was mixed with the same amount of virus which was diluted to contain approximately $10^{2} \mathrm{TCD}_{50}$ per $0.1 \mathrm{ml}$. These virus-serum mixtures were incubated at $37^{\circ} \mathrm{C}$ for 1 hour. Two-tenths $\mathrm{ml}$ of the mixtures was inoculated into a duplicate set of 5-day-old cultures. Four days after incubation the tubes were examined microscopically, and the absence of degeneration was interpreted as a positive neutralization test. For titration of the pooled serum, antibody titer was expressed in terms of the initial dilution which showed complete positive neutralization in the tubes examined.

Test for d character (1).

This character was determined by measuring the reduced efficiency of plating under a low bicarbonate agar overlay on MK and HeLa cells. In all tests, PFU per ml was compared in bottle cultures with 0.1 per cent and 0.4 per cent $\mathrm{NaHCO}_{3}$ in the overlay. The nutrient medium for agar overlay consisted of: 10 times Hanks solution $18 \mathrm{ml}$, sterile distilled water $61.3 \mathrm{ml}$ (or $52.6 \mathrm{ml}$ ), neutral red (1: 1000) $3.0 \mathrm{ml}$, calf serum $3.6 \mathrm{ml}, 7 \% \mathrm{NaHCO}_{3} 2.9 \mathrm{ml}$ (or $11.6 \mathrm{ml}$ ), $40,000 \mathrm{u} / \mathrm{ml}$ penicillin $1.0 \mathrm{ml}$ and $200 \mathrm{mg} / \mathrm{ml}$ dihydrostreptomycine $0.2 \mathrm{ml}$.

From the titer at the two bicarbonate concentrations the EOP (efficiency of plating) values were obtained for the test and control viruses, and the character of each strain was determined by the ratio of EOP to that of LSc. The strains were separated arbitrarily into three groups: $d^{-}$strain, having an EOP ratio to LSc greater than 0.75 ; intermediate, or $\mathrm{d}^{ \pm}$strains, having an EOP ratio to LSc of 0.30 to 0.74 ; and $\mathrm{d}^{+}$strains, having an EOP ratio to LSc of 0 to 0.29 .

\section{Test for T character (3).}

Parallel virus titrations were performed under two conditions: using $37^{\circ} \mathrm{C}$, and $40^{\circ} \mathrm{C}$ for the incubation of the inoculated MK cells cultures. The temperature variation of the $40^{\circ} \mathrm{C}$ incubation was $\pm 0.1 \mathrm{C}$. CPE titers were estimated on days $5,7,9$ and 11 of the test. The maintenance medium for MK cells consisted of $90 \%$ Melnick-Earles medium ( $0.5 \%$ lactalbumin hydrolysate in Earles salt solution), 10 $\%$ Carnation brand skim milk solution, $100 \mathrm{u} / \mathrm{ml}$ penicillin, $100 \mathrm{ug} / \mathrm{ml}$ dihydrostreptomycine. Parallel virus titrations were performed under two conditions: using $37^{\circ} \mathrm{C}$, and $40^{\circ} \mathrm{C}$ for the incubation of the inoculated cultures. The difference in titers obtained at the two temperatures was expressed as $\log _{10}$ EOG (efficiency 
of growth) values $\left(\log _{10} \mathrm{EOG}=\log \mathrm{TCD}_{50}\right.$ per $\mathrm{ml}$ at $37^{\circ} \mathrm{C}$ minus $\log \mathrm{TCD}_{50}$ per $\mathrm{ml}$ at $40^{\circ} \mathrm{C}$ ). The authors arbitrarily determined the $\mathrm{T}$ value of a strain by the ratio of EOG to that of LSc. Here again the strains tested were separated arbitrarily into three groups: $\mathrm{T}^{-}$strains-strains which had an EOG ratio to LSc greater than 0.75; intermediate or $\mathrm{T}^{ \pm}$strains-those having an EOG ratio to LSc of 0.30 to 0.74 ; and $\mathrm{T}^{-}$- strains-with an EOG ratio to LSc of 0 to 0.29 .

Test for MS character (2).

This character was determined by measuring the plaque on MS cells after 6 days of inoculation. Virus strain that produced tiny plaques smaller than $3 \mathrm{~mm}$ in diameter, or no plaques at all, were classified as $\mathrm{MS}^{-}$. On the other hand, strains that produced plaques larger than $6 \mathrm{~mm}$ on MS cells were considered to possess the $\mathrm{MS}^{+}$character of wild strains. The nutrient medium for agar overlay consisted of 10 times Hank's solution $18.0 \mathrm{ml}$, sterile distilled water $58.4 \mathrm{ml}$, neutral red (1: 1000) $3.0 \mathrm{ml}$, calf serum $3.6 \mathrm{ml}, \mathrm{NaHCO}_{3}(7.0 \%) 5.8 \mathrm{ml}, 40,000 \mathrm{u} / \mathrm{ml}$ penicillin $1.0 \mathrm{ml}$ and $200 \mathrm{mg} / \mathrm{ml}$ dihydrostreptomycine $0.2 \mathrm{ml}$. Agar solution consisted of 2.7 $\mathrm{g}$ water $90.0 \mathrm{ml}$. After sterilization and before use, it was cooled to $45^{\circ} \mathrm{C}$. Just before making the overlay, equal portions of the nutrient medium (at $37^{\circ} \mathrm{C}$ ) and the agar solution (at $45^{\circ} \mathrm{C}$ ) were mixed.

Test for CFt character (4).

This character was determined by the behavior of the heating antigen at various temperatures in the complement fixation test. When serial two-fold dilutions of antigen were tested against serial two-fold dilutions of homotypic sera, virus strains that indicated complement fixing ability of heating antigen at various temperatures the same or lower than nonheated antigen were classified as $\mathrm{CFt}^{-}$. On the other hand, the complement fixing ability of heating antigens at various temperatures higher than nonheated antigen were classified as $\mathrm{CFt}^{+}$. The virus strain whose highest complement fixing ability was indicated at $85^{\circ} \mathrm{C}\left(75^{\circ} \mathrm{C}, 65^{\circ} \mathrm{C}, 56^{\circ} \mathrm{C}\right)$ heating antigen was classified as $\mathrm{CFt}^{+}{ }_{85}\left(\mathrm{CFt}^{+}{ }_{75}, \mathrm{CFt}^{+}{ }_{65}, \mathrm{CFt}^{+}{ }_{56}\right)$.

\section{EXPERIMENTAL RESULTS}

\section{Cell susceptibility to ECHO viruses.}

To test the susceptibility of cells to ECHO viruses, titrations were performed using MK, MS, FL and HeLa cells. Table 2 gives the results of titrations of the same pool of each virus with the cells indicated.

Each virus represents different titers for different cells. The titer of ECHO 1 strain is 5.5 and 4.5 in $\log _{10}$ unit in the case of MK and FL cells, respectively. There is, therefore, a 1003-fold difference between the two cases. Thus, the susceptibility to viruses is more or less different with the cells used, but it is deemed advantageous in general to adopt MK cells in titrating these viruses.

It is quite worthy of notice that, the human origin cells (e.g., HeLa and FL) were superior as cells to MK cells for titration of ECHO 2, 5, 6" $, 7,9,11,12,13$, 14,19 and 24 strains. 
TABLE 2

Titration of ECHO viruses

\begin{tabular}{|c|c|c|c|c|}
\hline & HeLa & FL & MS & $\mathrm{MK}$ \\
\hline $\begin{array}{r}\text { ECHO } \\
2 \\
2 \\
3 \\
4 \\
5 \\
6 \\
6 \\
6 \\
7 \\
8 \\
9 \\
10 \\
11 \\
12 \\
13 \\
14 \\
15 \\
16 \\
17 \\
18 \\
19 \\
20 \\
22 \\
23 \\
24 \\
25\end{array}$ & $\begin{array}{r}4.8^{*} \\
7.2 \\
6.2 \\
<1.5 \\
\mathbf{6} .8 \\
7.8 \\
6.2 \\
>6.5 \\
6.8 \\
<2.5 \\
6.8 \\
<2.5 \\
6.8 \\
4.5 \\
6.2 \\
<2.5 \\
<1.5 \\
1.8 \\
<2.5 \\
<1.5 \\
7.2 \\
6.5 \\
<2.5 \\
<1.5 \\
6.5 \\
5.2\end{array}$ & $\begin{array}{r}<4.5 \\
<4.5 \\
<3.5 \\
<1.5 \\
3.8 \\
6.2 \\
<3.5 \\
5.2 \\
7.8 \\
<3.8 \\
7.8 \\
3.2 \\
7.5 \\
8.5 \\
\mathbf{6} .8 \\
6.8 \\
2.2 \\
1.8 \\
4.3 \\
2.0 \\
5.2 \\
<2.5 \\
<2.5 \\
<1.5 \\
>\mathbf{6 . 5} \\
5.5\end{array}$ & $\begin{array}{r}5.8 \\
5.5 \\
<3.5 \\
6.2 \\
6.2 \\
<3.5 \\
5.8 \\
2.8 \\
5.5 \\
<3.5 \\
3.2 \\
<2.5 \\
<1.5 \\
<1.5 \\
<2.5 \\
<2.5 \\
5.5 \\
3.8 \\
<2.5 \\
<1.5 \\
6.2 \\
4.5\end{array}$ & $\begin{array}{l}6.5 \\
6.8 \\
6.5 \\
3.8 \\
6.8 \\
8.5 \\
6.5 \\
5.2 \\
7.5 \\
\mathbf{5} .5 \\
6.2 \\
4.8 \\
7.2 \\
6.5 \\
4.2 \\
5.8 \\
4.2 \\
4.2 \\
5.5 \\
4.8 \\
6.2 \\
6.8 \\
3.5 \\
2.8 \\
6.5 \\
6.2\end{array}$ \\
\hline
\end{tabular}

* $\log _{10}$ titer per $1.0 \mathrm{ml}$

Flaque formation of ECHO viruses.

Though it was shown that ECHO viruses used in the present studies produced a cytopathogenic effect on MK, MS, FL and HeLa cells, the question remained whether those viruses could form a plaqe on such cells or not. The experiment was done to clarify the problem. The formation of plaques on the cells and the sizes are indicated in Table 3.

The formation and the size of plaques of each virus were different with different cells. In particular, ECHO 2, 3, 4, 14, 15, 16, 17, 18, 22 and 23 strains could form no plaque on any cell used in this experiment.

Effects of sodium bicarbonate concentration on plaque formation of ECHO viruses.

Tests for the d marker were performed in bottle cultures, using five to seven day old HeLa cell and MK cell monolayers grown and maintained in Melnick-Hank's medium. Parallel virus titrations were performed using $0.1,0.2$ and 0.4 per cent bicarbonate. The virus inoculum was $0.2 \mathrm{ml}$. Three bottles were used for each dilution. The virus titers were calculated on the basis of the plaque count on the day after virus seeding. The results are shown in Table 4 .

In the d marker test with HeLa cell, ECHO 6, 6", 11, 12 and 19 were found to be $\mathrm{d}^{+}$, ECHO 24 was found to be $\mathrm{d}^{ \pm}$. In the $\mathrm{d}$ marker test with MK cell, ECHO 19 was found to be $d^{+}$, ECHO 12 was found to be $d^{ \pm}$, and ECHO 24 was found to be $d^{-}$. 
TABLE 3

Piaque formation of ECHO viruses with Nahoney and Sabin type 1 strains used as controls

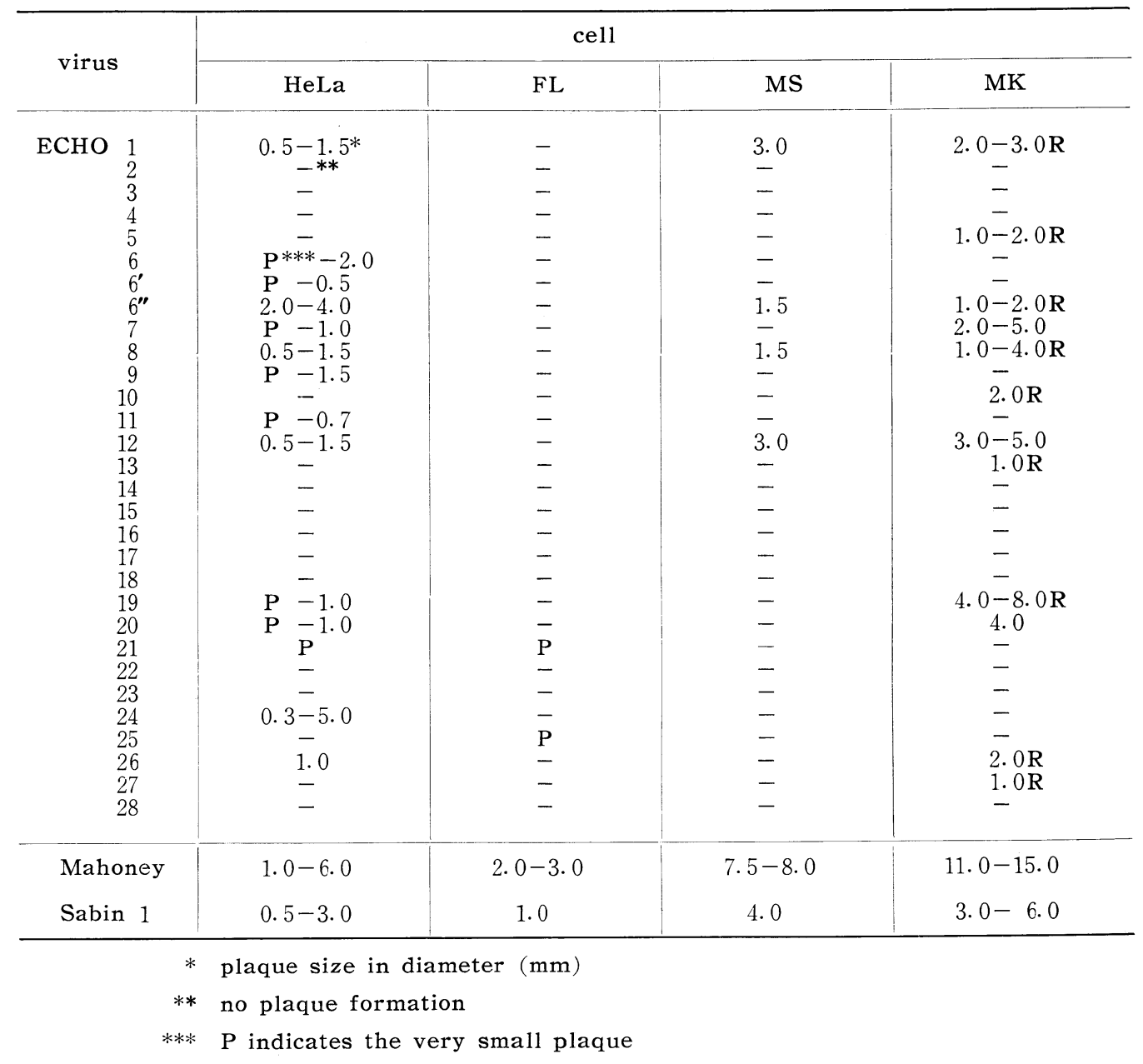

$T$ character test with ECHO viruses on $M K$ cells.

Each ten-fold dilution $\left(10^{-1}-10^{-7}\right)$ of ECHO virus was inoculated with $0.1 \mathrm{ml}$ in 8 tubes of MK cell. The tubes were divided into two groups, and incubated at $37^{\circ} \mathrm{C}$ for one group and at $4.0^{\circ} \mathrm{C}$ for the other, $\mathrm{CPE}$ was observed after 5,7 and 9 days, and calculated at $\mathrm{TCD}_{50}$ per $0.1 \mathrm{ml}$. The following procedures were the same as in the $\mathrm{d}$ marker test, and classified into three groups $\mathrm{T}^{+}, \mathrm{T}^{ \pm}$and $\mathrm{T}^{-}$. Mahoney and Sabin type 1 strains were used as control viruses. The results are shown in Fig. 1.

The strains tested were separated arbitrarily into three groups: ECHO 1, 5, 8, $13,15,17,18$ and 19 strain were found to be $\mathrm{T}^{+}$; ECHO 2, 3, 6, 6', 7, 9, 10, 11, 12, 16,22 and 23 strain were found to be $\mathrm{T}^{ \pm}$; ECHO $6^{\prime \prime}, 14,20,24$, and 25 strain were found to be $\mathrm{T}^{-}$. 
TABLE 4

Effect of sobium bicarbonate concentration on plaque formation of ECHO viruses

\begin{tabular}{|c|c|c|c|c|c|c|c|c|c|}
\hline \multirow{2}{*}{\multicolumn{2}{|c|}{ cells }} & \multicolumn{4}{|c|}{$\mathrm{HeLa}$} & \multicolumn{4}{|c|}{ MK } \\
\hline & & $0.1 \%$ & $0.2 \%$ & $0.4 \%$ & $\begin{array}{l}\text { cha- } \\
\text { racter }\end{array}$ & $0.1 \%$ & $0.2 \%$ & $0.4 \%$ & $\begin{array}{l}\text { cha- } \\
\text { racter }\end{array}$ \\
\hline $\mathrm{ECHO}$ & 6 & $6.4(1.0)$ & $<4.5(0)$ & $<4.5(0)$ & $d^{+}$ & - & - & - & \\
\hline ЕCHO & 6" & 6. 1(5-6) & $6.1(4-5)$ & $5.3(3)$ & $d^{+}$ & - & - & - & \\
\hline ECHO & 11 & $4.2(1.5)$ & 3. $9(1-1.5)$ & $<2.5(0)$ & $d^{+}$ & - & - & - & \\
\hline $\mathrm{ECHO}$ & 12 & 4. $4(1-1.5)$ & $4.4(1.5)$ & $<2.5(0)$ & $d^{+}$ & 4. $1(7-11)$ & $5.0(8-15)$ & $4.5(8-10)$ & $\mathrm{d}^{ \pm}$ \\
\hline ЕСHO & 19 & 5. $5(2)$ & $4.8(2)$ & 4. $4(1-2)$ & $d^{+}$ & 5. $0(11-13)$ & 4. 6(13) & $4.2(15)$ & $d^{+}$ \\
\hline ЕCHO & 24 & $4.0(6)$ & $4.3(9)$ & 3. $7(5-8)$ & $\mathrm{d}^{ \pm}$ & 3. $0(15)$ & 4. 1(15-20) & $4.3(18-20)$ & $d^{+}$ \\
\hline Mahon & & $5.3(6-8)$ & 5. 5(8-9) & 5. 6(8) & & 5. $2(15)$ & $5.7(16)$ & 5. $0(20)$ & \\
\hline Sabin & & 5. $2(3-4)$ & 5. $6(4-6)$ & $6.4(6-7.5)$ & & $3.8(5-7)$ & $4.9(12-14)$ & $4.7(11-16)$ & \\
\hline
\end{tabular}

Fig. 1 T MARKER TEST WITH ECHO VIRUSES

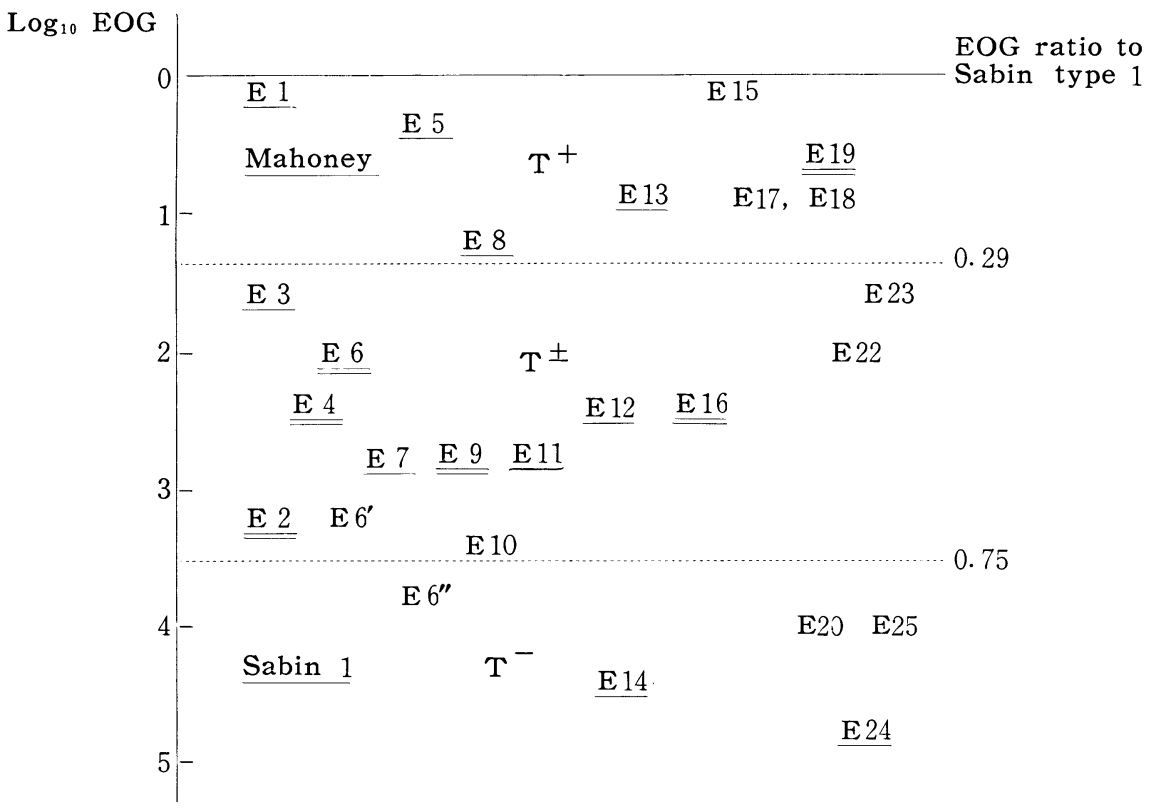

MS character test with ECHO viruses.

The procedures were the same as in the a marker test except for the constitution of overlay agar. Inoculated and overlaid monolayer was incubated for 6 days. Virus strains that produced tiny plaques smaller than $3 \mathrm{~mm}$ in diameter, or no plaques, were classified as $\mathrm{MS}^{-}$, larger than $6 \mathrm{~mm}$ as $\mathrm{MS}^{+}$, and the intermediate as 
MS ${ }^{ \pm}$Mahoney and Sabin type 1 strains were used as controls for virulent and attenuated virus. The results are shown in Fig. 2.

The all strains tested were found to be MS-.

\section{Fig. 2 MS MARKER TEST WITH ECHO VIRUSES}

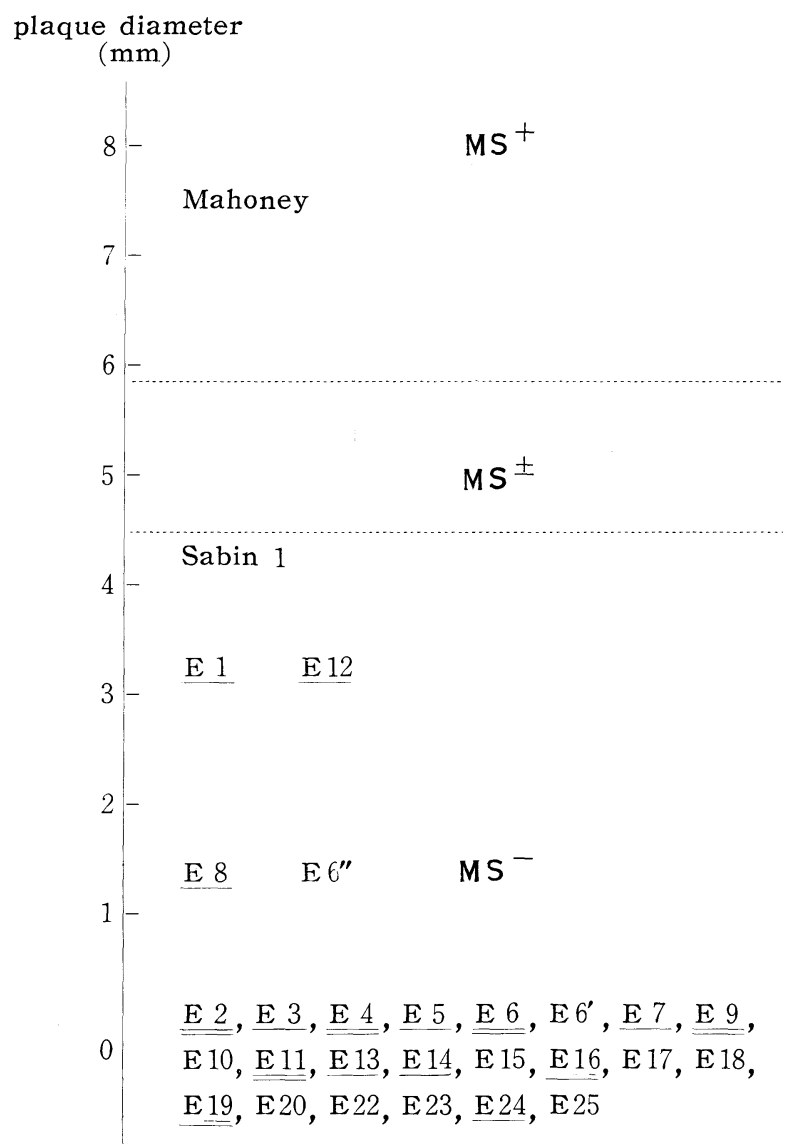

CFt character test with ECHO viruses.

Seventeen strains of ECHO virus were tested. The results are shown in Fig. 3. The strains tested were separated arbitrarily into two groups: ECHO 2, 5, 6 and 9 strains were found to be $\mathrm{CFt}^{+}{ }_{56}$, ECHO 1, 3, 7, 8, 10, 11, 12, 13, 14, 15, 16, 17 and 18 strains were found to be $\mathrm{CFt}^{-}$.

Immunizing capacity test of ECHO virus using monkey.

Thirteen monkeys were used for immunization to clarify the capacity of antigenicity of ECHO virus with Sabin type 1 strain used as controls in this test, and neutralizing antibody titer of the antiserum was measured. According to the procedure of immunization given in Fig. 4, 13 antisera of ECHO 12, ECHO 19 and Sabin type 1 strain were prepared. The neutralizing antibody titer of each serum was 
Ftg. 3 CFt MARKER TEST WITH ECHO VIRUSES

\begin{tabular}{|c|c|c|c|c|c|}
\hline & $\mathrm{CFt}^{-}$ & $\mathrm{CFt}^{+}{ }_{58}$ & $\mathrm{CFt}^{+}{ }_{60}$ & $\mathrm{CFt}^{+}{ }_{65}$ & $\mathrm{CFt}^{+}{ }_{75}$ \\
\hline POLIO & $\begin{array}{l}\text { Sabin } 1,2,3 \\
\text { Lederle } \\
\text { YSK } \\
\text { Leon }\end{array}$ & & $\mathrm{MEF}_{1}$ & & Mahoney \\
\hline ECHO & 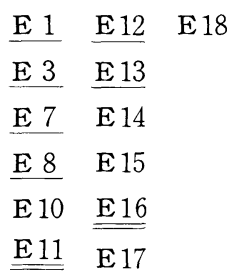 & $\begin{array}{l}\underline{\text { E } 2} \\
\text { E 5 } \\
\text { E 6 } \\
\text { E 9 }\end{array}$ & & & \\
\hline
\end{tabular}

Fig. 4 IMMUNIZING CAPACITY TEST

VIRUS 7.0 $\mathrm{TCD}_{50} / \mathrm{ML}$

$\left.\begin{array}{ll}\text { VIRUS } 7.0 \mathrm{TCD}_{50} / \mathrm{ML} & 5 \mathrm{ML} \\ \text { COMPLETE ADJUVANT } & 5 \mathrm{ML}\end{array}\right\} 10 \mathrm{ML}$ i. m.

$\downarrow 10$ DAYS

$\left.\begin{array}{ll}\text { VIRUS } & 5 \mathrm{ML} \\ \text { COMPLETE ADJUVANT } & 5 \mathrm{ML}\end{array}\right\} 10 \mathrm{ML}$ i.m.

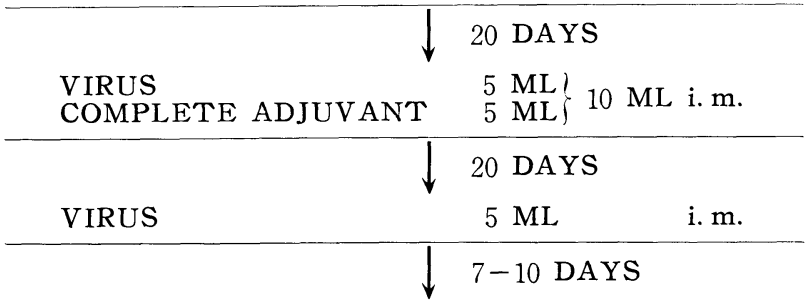

Fig. $\quad 5$

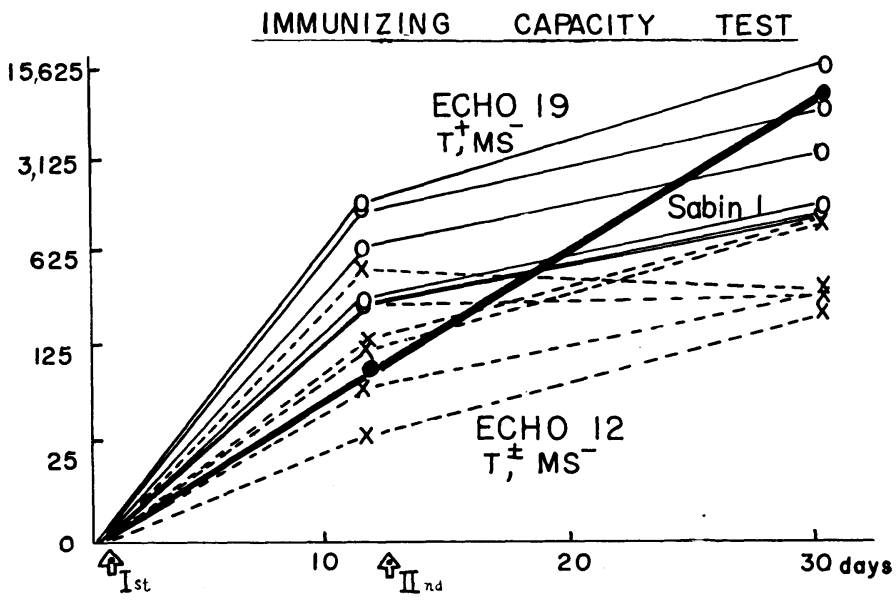


measured against homotypic virus, and the results are shown in Fig. 5. The results of the in vitro marker test of each virus are indicated in Fig. 5.

The virulent strain (ECHO $19 \cdots \ldots . \mathrm{T}^{+} \mathrm{MS}^{-}$) represents undoubtedly higher titers than the attenuated strain (ECHO $\left.12 \cdots \cdots . \mathrm{T}^{ \pm} \mathrm{MS}^{-}\right)$. From these results, the relationship between virulence and antigenicity — the more virulent the virus, the higher the antigenicity — could be elucidated in ECHO virus using in vitro markers as in polio virus.

\section{DISCUSSION}

The increased use of tissue culture methods in the field of virology has resulted in the discovery of many cytopathogenic agents. These viral agents may be derived from the tissues and excreta of man; many of them defy detection by methods other than cell cultivation.

These agents have been celled "orphan" virus because we know so little about the diseases with which they many be associated. As so many of them have been isolated from the intestinal tract, they have been considered with the enteroviruses. (12) (13) (14) (15)

The growth of animal virus in cells under agar produces areas of necrosis resulting in virus colonies or plaques. Differences in plaque patterns produced by various enteroviruses have been noted by many investigators: for instance, Hsiung and Melnick's (16) previous studies on the enteroviruses have shown that poliovirus Type I, II, and III produce large, circular plaques with clear centers and sharp boundaries within 4 or 5 days after seeding on rhesus monkey kidney cultures. And, in plaque morphology and cell susceptibility of rhesus and patas cultures, ECHO viruses can be placed into two groups. Group A contains ECHO virus Type 1, 3, 4, 6', 9, 11, $13,14,15,16,17,18$ and 19 ; these produce small, irregularly shaped, hazy plaques in rhesus cultures, but are negative in patas cultures. Plaques of ECHO Type 1 and and ECHO type 13 are clearer in the centers; occasionally, with large inocula of these types, tiny dalayed plaques appear on patas cultures. Group B contains ECHO types 7, 8 and 12; these ECHO types are positive in patas cultures as well as in rhesus cultures. ECHO type 7 produces large circular plaques resembling those of poliovirus in both rhesus and patas cultures. ECHO type 8 produces smaller and more irregular plaques on rhesus cultures and tiny delayed plaques on patas cultures. ECHO type 12 produces large circular plaques on rhesus, but small irregular plaques on patas cultures. The proto type strain of ECHO types 2, 3, 5, 6 and 10 has not produced plaques.

In this study, ECHO virus plaques are more irregular in shape than poliovirus plaques within 4 or 5 days after seeding on cynomolgus monkey (Macaca irus) kidney culteres; exceptions are types 7,12 and 20 which form plaques that are almost impossible to distinguish from those of the polioviruses. On the other hand, minute plaques with sharp boundaries appeared as early as 4 days after inoculation into bottle cultures of HeLa cells, and enlarged, although slowly, thereafter. The HeLa cells might serve as a useful cell line for the comparative assay of ECHO viruses.

Though the virulence test using a monkey has been widely recognized as the best method, the eccnomic and technical difficulties do not readiealy permit experimentation in the laboratcry. 
Vogt and Dulbecco (1) have reported that the plaque formation on primary monkey kidney cells of most attenuated strains of poliovirus is dalayed or inhibited when the amount of bicarbonate in the agar overlay is reduced. This important finding has permitted the use of plaque count methods for in vitro marker of poliovirus virulence. But, on the hand, it is known that a number of attenuated strains of the $d^{-}$type have been shown to be capable of reversion to the wild, $d^{+}$type, without markedly changing their low degree of neurovirulence in tests on a monkey (10) (11).

Kanda and Melnick (2) have observed that MS character may be used to differentiate poliovirus particles. Strains that produced relatively large plaques on a monkey stable (MS) cell line were found to include highly virulent poliovirus strains; they were considered to be MS mutant. Attenuated strains appeared deficient in this gene, for they produced tiny plaques or no visible plaques at all; they were considered to be MS- mutant. And strains of maximum neurovirulence for Mahoney possessed $\mathrm{MS}^{+}$and $\mathrm{d}^{+}$character, while those of greatest attenuation were $\mathrm{MS}^{-} \mathrm{d}^{-}$. Strains possessing the $\mathrm{MS}^{+} \mathrm{d}^{-}$character showed high or intermediate attenuation.

Lwoff and Lwoff (3) have observed the $T$ character. This character was determined by measuring the reduced efficiency of growth under high temaperature $\left(40^{\circ} \mathrm{C}\right)$ incubation on monkey kidney cells. An appreciable parallelism was found between $\mathrm{d}$ character and $\mathrm{T}$ character.

Shingu (4) has observed the CFt marker. Virus strains that indicated complement fixing ability of heating antigens at various temperatures the same or lower than the nonheated antigen were classified as $\mathrm{CFt}^{-}$. On the other hand, the complement fixing ability of heating antigens at various temperatures higher than the nonheated antigen were classified as $\mathrm{CFt}^{+}$.

Shingu (5) has observed the A character. This character was determined by measuring the reduced efficiency of growth on the primary humam amnion cells.

Hodes et al. (6) have observed the $\mathrm{E}$ marker. This character was determined by the pattern of elution of a virus strain from the DEAE column.

In addition, McBride (7), Gard (8) and Wecker (9) have provided laboratory workers with a tool which permits serologic differentiation between strains of the same type.

Virulent, wild poliovirus strains possess $\mathrm{d}^{+}, \mathrm{MS}^{+}, \mathrm{T}^{+}, \mathrm{CFt}^{+}, \mathrm{A}^{+}, \mathrm{E}^{+}$markers and thus differ from most attenuated strains.

At present, six in vitro markers, d, MS, T, A, CFt and E are known which are thought to be related to virulence of poliovirus.

These markers never have an indentical nature and predisposition, but it is not natural to consider that the virulence is determined by only one marker in the course from infection in the living body to multiplication in nervous cells. The authors are now studying the possibility that the virulences, i.e., adsorbing ability of the intestinal canal, multiplication ability in the intestinal canal, transfering ability into the blood, or neuroaffinity to or multiplicating ability in nervous cells, might be determined by certain combinations of different markers.

Several ECHO viruses have been found to be causative agents of neurologic disease in man. Paralysis has occurred in individual patients infected with some of these viruses. The reports of Arnold and Enders (17) leave no doubt that muscle weakness and pleocytosis of cerebrospinal fluid can be induced in monkeys experimentally infected with ECHO 6 and 16 strain. 
The problem of the in vitro marker of ECHO viruses, that is to say, whether the in vitro marker test can be used in the ECHO viruses employing the same method as for poliovirus, has been an interesting difficulty in the field of the virulence of enteroviruses.

ECHO 6, 6" 11,12 and 19 strain are found to be $\mathrm{d}^{+}$, ECHO 24 strain is found to be $\mathrm{d}^{-}$. Eight (ECHO 1, 5, 8, 13 15, 17, 18 and 19 strains) of 26 ECHO strains possessed the $\mathrm{T}^{+}$character and thirteen (ECHO 2, 3, 4, 6, 6', 7, 9, 10, 11, 12, 16, 22 and 23 strains) were $\mathrm{T}^{ \pm}$, five (ECHO $6^{\prime \prime}, 14,20,24$ and 25 strains) were $\mathrm{T}^{-}$. On the other hand, all of 26 ECHO strains possessed the MS- character.

Thirteen (ECHO 3, 7, 8, 10,11, 12, 13, 14, 15, 16, 17 and 18 strains) of 17 ECHO strains possessed the $\mathrm{CFt}^{-}$character and four (ECHO 2, 5, 6 and 9 strains) were $\mathrm{CFt}^{+}{ }_{56}$. As may be seen, there is some semblance between the $\mathrm{d}$ marker and $\mathrm{T}$ marker of the ECHO virus strain. But, in contrast, there is no parallel between the $\mathrm{d}, \mathrm{T}$ markers and the MS, CFt markers.

It is logical to suppose that the $d, T$ markers of enteroviruses can express the multiplicating ability in nervous cells, and MS, CFt markers of enteroviruses can express the neuroaffinity to nervous cells. But, this problem should be discussed when a new method for analysis of neurovirulence is obtained.

Yamamoto and Shingu (18) found that the neutralizing antibody titers were higher in patients who excreted virulent polioviruses shown as $\mathrm{d}^{+}, \mathrm{T}^{+}, \mathrm{MS}^{+}, \mathrm{CFt}^{+}$ than in patients who excreted attenuated viruses shown as $\mathrm{d}^{-} \mathrm{T}^{-} \mathrm{MS}^{-} \mathrm{CFt}^{-}$, and these was close relatonship between polioviruses and their antigenicity.

Concerning immunizing capacity test of ECHO 12 and 19 strains, it was established that the ECHO 19 strain $\left(\mathrm{T}^{+} \mathrm{MS}^{-}\right)$possessed high immunogenicity and the ECHO 12 strain $\left(\mathrm{T}^{ \pm} \mathrm{MS}^{-}\right)$possessed lower immunogenicity than the ECHO 19 strain.

\section{SUMMARY}

In this communication a report is made on cell susceptibility, the in vitro marker test of ECHO viruses and their antigenicity. The results are summarized as follws :

Though HeLa, FL, MS and MK (cynomolgus monkey primary kidney) cells were susceptible to various types of ECHO viruses, some viruses could form no plaques on the cells. The HeLa cells might serve as a useful cell line for the titration and plaque assay of ECHO viruses.

ECHO 6, 6" 11,12 and 19 strains were found to be $\mathrm{d}^{+}$, ECHO 24 strain was found to be $\mathrm{d}^{-}$. ECHO 1, 5, 8, 13, 15, 17, 18 and 19 strains possessed the $\mathrm{T}^{+}$ character, and ECHO 2, 3, 4, 6, 6', 7, 9, 10, 11, 12, 16, 22 and 23 strains were $\mathrm{T}^{ \pm}$, while ECHO $6^{\prime \prime}, 14,20,24$ and 25 strains were $\mathrm{T}^{-}$.

On the other hand, all of 26 ECHO strains possessed the MS- character. ECHO $1,3,7,8,10,11,12,13,14,15,16,17$ and 18 strain possessed the $\mathrm{CFt}^{-}$character, and ECHO 2, 5, 6 and 9 strain were $\mathrm{CFt}^{+}{ }_{56}$.

The correlation between in vitro markers of ECHO virus and antibody titer of serum in animal immunization was examined. A linear relationship was found to exist between the virulence of ECHO virus and serun antibody titer in animal immunization. The relationship between the virulence of ECHO viruses and their antigenicity will be discussed. 


\section{BIBLIOGRAPHIES}

1. Vogt, M., Dulbecco, R. and Wenner, H. A. : Mutants of poliomyelitis viruses with reduced efficiency of plating in acid medium and reduced neuropathogenicity. Virology, 4, 141, 1957.

2. Kanda, Y., and Melnick, J. L. : In vitro differentiation of viruent and attenuated polioviruses by their growth caracteristics on MS cells. J. Exp. Med., 109, 9, 1959.

3. Lwoff, A. and Lwoff, M. : Remarques sur quelques caracteres du developpement du virus de la poliomyelite. C. rend. Acad. Sc. 248, 1725-1727, 1959.

4. Shingu, M. : Studies on the complement fixation test with enteroviruses. Effects of heating antigens at various temperatures on their complement fixing ability. Kurume Med. J., 8, 43-60, 1961.

5. Shingu, M. : Study on the in vitro differentiation of virulent and attenuated poliovirus by their growth characteristics on primary human amnion cells. Virus, 10, 346, 1961 (in Japanese)

6. Hodes, H. L., Zepp, H.D. And Ainbender, E. : A physical property as a virus markers. Difference in avidity of cellulose resin for virulent (Mahoney) and attenuated (LSc, $2 \mathrm{ab})$ strain of type 1 poliovirus. Virology, 11, 306-308, 1960.

7. MC Bride, W.D. : Antigenic analysis of polioviruses by kinetic studies of serum neutralization. Virology, \%, 45-58, 1959.

8. Gard, S. : Immunologic strain specificity within type 1 poliovirus. Bll. World Health Org. 22, 235-252, 1960.

9. WECKER, E. : A simple test for serodifferentiation of poliovirus strains within the same type. Virology, 10, 376-379.

10. Dulbecco, R. and Vogt, M. : Study of the mutability of d lines of polioviruses. Virology, $5,220,1958$.

11. Hsiung, G.D. and Melnick, J. L. : Effect of sodium bicarbonate concentration on plaque formation of virulent and attenuated polioviruses. J. Immunol., 80, 282, 1958.

12. Melnick, J.L. : Advances in the study of the enteroviruses. Progress in medical virology 1, 59-105, 1958.

13. Melnick, J. L. : Role of tissue cultures in the isolation and study of virus. 1 ECHO viruses. special publications of the New York Academy of Sciences, V, 365-381, 1957.

14. Syverton, J.T. : An appraisal of the enterovirus problem. Am. J. Trop. Med. and Hyg. 8, 101-109. 1959.

15. Melnick, J.L. et al. : Classification of human enteroviruses. Virology, 501-504, 1962.

16. Melnick, J. L., Hsiung, G. D., Rappaport, C., Howes, D. and Reissig, M. : Factors influencing the proliferation of viruses. Tex. Rep. Biol. Med. 15, 496-533, 1957.

17. Arnold, J.H. and Enders, J.F. : Disease in Macacus monkey inoculated with ECHO viruses. Proc. Soc. Exp. Biol. Med., 101, 513-516, 1959.

18. Shingu, M., Yamamoto, S. and Nakagama, Y. : Studies on the relationship between viru lence of poliovirus and their antigenicity. Kurume Med. J. 9, 205-216, 1962. 